\title{
APPROPRIATE ENVIRONMENTAL MANAGEMENT OF ELECTRICITY GENERATION FROM RENEWABLE ENERGY
}

\author{
W. PHOOCHINDA \\ Graduate School of Social and Environmental Development, National Institute of \\ Development Administration, Thailand.
}

\begin{abstract}
This study aimed at investigating and in turn assessing the environmental impacts caused by electricity generation using renewable energy of very small power producer (VSPP) and, then suggesting appropriate environmental management for the VSPP. Interviewing officers and regulators of the relevant organizations and also the environmental management personnel of the 13 VSPP studied was carried out. In addition, observing environmental impact and management of electricity generation of the VSPP studied were carried out. Although renewable energy is considered quite clean, using them in electricity generation results in some environmental impacts that affect environment and community. There is yet no environmental measure and standard clearly applicable for power plants $<10 \mathrm{MW}$ or VSPP to do environmental impact assessment (EIA) and, in addition, the existing standards for pollution emissions do not cover all types of pollutions occurring. It is thus of interest of this study. The results showed that wind and solar energy produce less environmental impacts compared with other renewable energy. Biomass and refuse-derived fuel energy produce more environmental impacts in particular, air pollution in each process of the electricity generation. There should be measures for environmental management of VSPP to prevent and manage environmental impacts - to prepare adequate raw materials in the vicinity of the power plant as well as their back up, to prevent spillage and particle emissions from raw material transportation, to store raw materials in a proper condition and far away from community, to use efficient technology resulting in complete combustion and to recycle and treat waste incurred.

Keywords: Renewable energy, environmental impact, environmental management, VSPP.
\end{abstract}

\section{INTRODUCTION}

As energy is necessary for human's daily living, a secure, sufficient and accessible energy supply is very important. Households, power plants, manufacturing industries and transportation mainly use non-renewable energy or fossil fuels such as coal, oil and natural gas. These fossil fuels have been gradually decreasing and are very likely to be scarce in the future. A study by Beyond Petroleum (2010) said that if the use of energy is more or less the same and the production of the energy remains more or less constant, the reserved energy since 2009 can be utilized as follows; oil can be used for 42 years, natural gas for 60 years and coal for 122 years [1]. This indicated that there will be a shortage of fossil fuels. Most of the fossil fuels especially $90 \%$ of the oil has to be imported from aboard leading to unsecured energy supply. Fossil fuels have also caused many environmental problems such as air pollution and other pollutions. Renewable energy can now meet $13.5 \%$ of the global energy demand [2]. It is easily accessible and abundant in Thailand as nature resources such as biogas, small-hydro and solar energy for electricity generation. In addition, as Thailand is an agricultural country, with many crops and appropriate topography and climates, alternative energy can be produced from biomass. New power plants have been constructed to satisfy the increasing demand for electricity that approximately rises by 1,400 MW per year, equivalent to the production capacity of two new electricity power plants each year.

Renewable energy such as small hydro sources and biomass energy are gaining interest in electricity generation for their practicality, as they are widely available and environmental friendly, make the effective use of the natural resources, help reduce the dependence on imported energy and fortify the country's energy supply; all of which are in accordance with His Royal Highness of Thailand's 
principle of the Philosophy of Sufficiency Economy. As a result, the government has various policies in support of electricity production from renewable energy such as adder cost and tax incentive. Although environmental impacts caused by electricity generation from renewable energy are relatively smaller when compared with the electricity currently produced from non-renewable energy, the impacts are still considerable, especially those resulting from the combustion of non-renewable energy.

Nowadays, the organizations concerned have issued certain measures and standards related to the environmental impacts from electricity generation; for example, ambient air quality standards, control standards for air emissions from new power plants, control standards for air emissions from new or old power plants that exploit co-firing, control standards for air emissions from old power plants and control standards for the waste water resulting from electricity generation. Overall, the control standards imposed on the power plants, especially those old ones, are based on the capacity of their electricity generators rather than on the pollutants emitted [3]. For the new power plants, different energy sources exploited result in different control standards applied. The measures and standards aforementioned are applicable to large-scale power plants with over $10 \mathrm{MW}$ of production capacity, and do not cover other possible environmental impacts such as those caused by noise, solid waste and water pollution. This leads to double standards in environmental management, as pollutants, no matter what type or from what production step and from a power plant of any size, can adversely affect the environment.

Double standards involve inequality and discrimination. One of the evident problems concerning double standards is the socio-economic inequality resulting in a wide gap between the rich and the poor, leading to discrimination and finally conflicts. Double standards in environmental management range from double standards in access to the resources and double standards resulting from inefficiency in environmental management. Similarly, the double standards in imposing measures in the environmental management of the non-renewable energy power plants that are not applicable to all sizes of power plants and pollutants incurred in every step of their production can possibly lead to significant environmental problems in the future.

Investigation of the environmental impacts resulting from very small power producers (VSPPs) is, therefore, of importance. This should include the selection, transportation and transference of raw materials, electricity generation and pollutant management during production and recycling of the waste incurred. The existing domestic measures and standards in environmental management, as well as those used in other countries, are then referred to. Since there is no yet any definite measure or standard applicable to VSPP using renewable energy, the author is keen to investigate on every step of their environmental management in order to be able to suggest appropriate measures in dealing with the environmental problems and impacts incurred. With definite measures in the environmental management applicable to VSPPs in their every step of production - be it the material selection or the disposal of the waste incurred - and regarding any material they use - be it water, solid waste, or geothermal energy; certain standards that are not based on the approaches to the problems incurred by large size power producers can be set. Thus, the objectives of this study are to analyze the environmental impacts resulting from VSPP using renewable energy and to suggest appropriate environmental management for VSPP using renewable energy.

\section{LITERATURE REVIEW}

\subsection{Environmental problems resulting from electricity generation}

Environmental problems incurred from electricity generation depend on the energy exploited. Though renewable energy is certainly far more environmental friendly than fossil energy, it can negatively affect water and air, as well as produce noise and solid waste. These problems are to be discussed in the following. 


\subsubsection{Use of water resource}

In electricity generation, water is required for producing steam in the boiler, cooling, washing the equipment and for other purposes. The amount of water and the impacts incurred depend on the technology and method employed, which are to be discussed as follows:

1. As a raw material used directly in the form of hydro energy, which affects the animate beings inhabiting the water, ecology, as well as animals and men using the water from the source. The extraction of the upper part of the waters can adversely affect the aquatic flora and fauna. This is so because the waters coming to replace from the bottom have lower temperature and much less oxygen, which are not suitable for the growth of living things.

2. As used along with biomass and fossil fuel in producing steam. Water resource is used in electricity generation, in which the water is boiled and the steam of which is used to drive turbines that in turn drive generators. As such water is extracted from streams or rivers, the ecology and aquatic living beings can be negatively affected.

3. As used in the cooling process. In electricity generation, the apparatus and engines employed tend to overheat; as a consequence, cooling is necessary in reducing their temperature.

4. As used for other purposes.

- Coal: water is used in coal mining and in removing contaminant compounds in coal.

- Oil: water is used in oil drilling and oil refinery.

- Geothermal energy: water is injected into the drilled hole to extract the power in the form of hot spring and hot steam.

- Cleaning of apparatus: such as turbines, solar cells, etc.

For the use of solar power, wind power and landfill gas, no water is needed in the electricity generation process.

\subsubsection{Air pollution}

According to the data from US EPA [4], in the US, electricity generation causes more air pollution problems than other activities do. The percentage of sulfur dioxide, nitrogen oxide and carbon dioxide emission is $67 \%, 23 \%$ and $40 \%$, respectively, of all the emission of these gases from all other activities.

As shown in Table 1, with respect to the amounts of air pollution caused by different types of energy used in $1 \mathrm{MW}$ of electricity generation, carbon dioxide is emitted most in solid waste-fired electricity generation and coal-fired electricity generation. Sulfur dioxide is emitted considerably more in the electricity generation from coal and oil compared with the generation of the same amount of electricity when other sources of energy are used. And nitrogen oxide is emitted more in the electricity generation from coal, oil and solid waste combustion than from other types of energy.

Despite no air pollution resulting from combustion, there may be some other types of emissions caused in the use of certain energy sources in electricity generation. For example, in the use of hydro energy, there is some methane from the decomposition of aquatic plants living in that water source. Or in the use of nuclear power, the processes of uranium mining and transportation bring about air pollution.

\subsubsection{Water pollution}

Water is used as a raw material in certain types of energy production. Some part of the water can be reused. And some is disposed as wastewater, which unless properly treated is usually contaminated. Water pollution can also be caused by mining and in energy extraction processes. Water pollutants categorized according to the energy source employed in electricity generation are shown in Table 2. 
Table 1: Air pollution caused by different types of energy used in $1 \mathrm{MW}$ of electricity generation (adapted and concluded from US EPA [4]).

\begin{tabular}{|c|c|c|c|c|}
\hline Energy & $\begin{array}{l}\text { Carbon dioxide } \\
\text { (lbs) }\end{array}$ & $\begin{array}{l}\text { Sulfur dioxide } \\
\text { (lbs) }\end{array}$ & $\begin{array}{l}\text { Nitrogen oxide } \\
\text { (lbs) }\end{array}$ & Other pollutants \\
\hline Coal & 2,249 & 13 & 6 & Methane \\
\hline Natural gas & 1,135 & 0.1 & 1.7 & Methane \\
\hline Oil & 1,672 & 12 & 4 & $\begin{array}{l}\text { Methane } \\
\text { Mercurial composites }\end{array}$ \\
\hline Nuclear & - & - & - & $\begin{array}{l}\text { Pollution from uranium } \\
\text { transportation }\end{array}$ \\
\hline \multicolumn{5}{|l|}{ Solid waste } \\
\hline Combustion & 2,988 & 0.8 & 5.4 & Mercurial composites \\
\hline Landfill & - & - & Small & $\begin{array}{l}\mathrm{CO}_{2} \text { (small amount and } \\
\text { is used in natural carbon } \\
\text { cycle) }\end{array}$ \\
\hline Wastewater & - & - & - & $\begin{array}{l}\text { Methane } \\
\text { Hydrogen sulfide }\end{array}$ \\
\hline Biomass & - & Small & Small & $\begin{array}{l}\mathrm{CO}_{2} \text { (small amount and } \\
\text { is used in natural carbon } \\
\text { cycle) }\end{array}$ \\
\hline Hydro & - & - & - & $\begin{array}{l}\text { Methane from } \\
\text { decomposition of plants }\end{array}$ \\
\hline $\begin{array}{l}\text { Solar, wind and } \\
\text { geothermal energy }\end{array}$ & - & - & - & - \\
\hline
\end{tabular}

\subsubsection{Solid waste generation}

Solid waste is incurred in certain processes of electricity generation, the disposal of which is by landfilling. If the waste is contaminated or considered dangerous, appropriate methods must be applied. Solid waste resulting from electricity generation can be categorized according to the energy source employed as in Table 3.

\section{RESEARCH METHODOLOGY}

To collect the data in this study, the literature concerning the existing standards and measures in the environmental management of the power plants imposed by relevant organizations is reviewed and officers and regulators of the relevant organizations such as Ministry of Energy, Ministry of Industrial Work and Pollution Control Department are interviewed. In addition, the electricity generation and environmental management of VSPPs using renewable energy are observed, their officers in charge thereof are interviewed.

The target subjects are VSPP using renewable energy with the production capacity of $<10 \mathrm{MW}$, including two biomass power plants, three refuse-derived power plants, one biogas power plant, two wind energy power plants, two hydroelectricity plants, one geothermal power plant and two solar power plants. 
Table 2: Water pollutants categorized according to the energy source employed in electricity generation.

\begin{tabular}{|c|c|}
\hline Energy source & Water pollutant \\
\hline Coal, oil, natural gas & $\begin{array}{l}\text { Water from steam boilers, water from the cooling } \\
\text { process, waste water from water conditioning process } \\
\text { prior to steam boiling, wastewater from cleansing of } \\
\text { particulates } \\
\text { - In coal mining, water may be contaminated with metals } \\
\text { such as arsenic and lead } \\
\text { - In oil drilling, underground water can be contaminated. } \\
\text { There can be leakage in oil transportation }\end{array}$ \\
\hline Nuclear & $\begin{array}{l}\text { - Water from the cooling process, which is very high in } \\
\text { temperature } \\
\text { - Water contaminated with metal resulting from mining } \\
\text { and electricity generation }\end{array}$ \\
\hline \multicolumn{2}{|l|}{ Solid waste } \\
\hline Firing to produce heat & $\begin{array}{l}\text { Water from steam boilers, water from the cooling } \\
\text { process, wastewater from water conditioning process } \\
\text { prior to steam boiling, wastewater from cleansing of } \\
\text { particulates }\end{array}$ \\
\hline Landfilling for biogas production & - Water from cleansing of solid waste \\
\hline $\begin{array}{l}\text { Wastewater used for biogas } \\
\text { production }\end{array}$ & $\begin{array}{l}\text { Water from the treatment of contaminated biogas such as } \\
\text { from the wet scrubber, prior to the electricity generation } \\
\text { process }\end{array}$ \\
\hline Biomass & $\begin{array}{l}\text { Water from steam boilers, water from the cooling process, } \\
\text { waste water from water conditioning process prior to steam } \\
\text { boiling, wastewater from cleansing of particulates } \\
\text { Water contaminated with chemicals and insecticides used in } \\
\text { biomass culture }\end{array}$ \\
\hline Hydro, solar and wind energy & None \\
\hline Geothermal energy & $\begin{array}{l}\text { Underground water can be contaminated in the drilling } \\
\text { process }\end{array}$ \\
\hline
\end{tabular}

\subsection{Data-collection tools}

1. In-depth interview of officers and regulators of the relevant organization, the topics include the step of licensing process of small power producer and VSPP, policies, measures and regulations of environmental management of electricity generation using renewable energy. An impact of international policies and measures on environmental management on Thai's policies of electricity generation using renewable energy was also used for interviewing. The opinion on the existing standards and measures in the environmental management of the power plants, opinions on the action of the power plants on the standards and measures of environmental management, and obstacles and problems on following the standards and measures in environmental management of the power plants were also addressed. 
Table 3: Solid waste resulting from electricity generation categorized according to the energy source employed (adapted and summarized from US EPA [4]).

\begin{tabular}{|c|c|}
\hline Energy source & Solid waste incurred \\
\hline Coal & $\begin{array}{l}\text { Around } 10 \% \text { of ash resulting from combustion } \\
\text { In addition, there are toxic particulates and gases incurred in coal } \\
\text { mining and removal of coal contaminants }\end{array}$ \\
\hline Oil & $\begin{array}{l}\text { Residues left behind after wastewater treatment } \\
\text { Soot from incomplete combustion }\end{array}$ \\
\hline Natural gas & The amount of waste incurred is negligible \\
\hline Nuclear & $\begin{array}{l}\text { The total amount of nuclear waste produced by the nuclear power } \\
\text { plants in the US is approximately } 2,000 \text { tons per year }\end{array}$ \\
\hline \multicolumn{2}{|l|}{ Solid waste } \\
\hline Combustion & $\begin{array}{l}\text { Ash resulting from combustion. In addition, there are toxic gas and } \\
\text { particulates incurred in air pollution treatment }\end{array}$ \\
\hline Landfilled biomass & $\begin{array}{l}\text { Non-biodegradable, but no solid waste is incurred in the process } \\
\text { of electricity generation, ash resulting from combustion, which } \\
\text { usually contains no hazardous waste }\end{array}$ \\
\hline $\begin{array}{l}\text { Hydro, wind, solar and } \\
\text { geothermal energy }\end{array}$ & None \\
\hline
\end{tabular}

2. In-depth interview of the electricity generation of VSPPs, the topics of which include processes in electricity generation, problems and obstacles in electricity generation, management of raw materials, policies and measures in the environmental management in each step, and their opinion on the government policies, measures and regulations concerning electricity generation.

3. Observation forms related to each step of electricity generation, including the general condition of the plant and its surroundings, management of raw materials, electricity generation, pollution treatment and recycling.

\section{RESULTS AND DISCUSSION}

In this study, the findings are reported in four related parts. The first part presents on the results of interviewing of the relevant organizations. The second part reports the technical characteristics of the power plant under analysis-energy production and electricity generation. The third part reports on the analysis of the environmental impacts resulting from electricity generation by VSPP. And the fourth part discusses the measures in environmental management and solution of the existing environmental impacts.

\subsection{Opinion of the officers and regulators of the relevant organizations}

In the opinion of the officers and regulators, the policies and measures in the environmental management of electricity generation using renewable energy do not include all pollutions resulted from electricity generation using renewable energy and, in addition, it involves mainly on air pollution. Moreover, only the power plant producers that produce $>10 \mathrm{MW}$ have to do Environmental Impact Assessment, but the ones produce $<10 \mathrm{MW}$ are not requested to do this although they also produce 
pollution as well. According to the existing standard of environmental emissions, it is sensible and follows to the international standards like US EPA. For policies and measures in environmental management, there are responsible units for monitoring pollution emissions but their policies and measures need to be integrated.

4.2 Energy production and electricity efficiency of the power plant studied

In this study, 13 VSPPs were surveyed and their technical characteristics of the power plant in this study - electricity production and their production cost and average electricity efficiency - are shown in Table 4.

Table 4: Energy production and electricity efficiency of the power plant studied.

\begin{tabular}{|c|c|c|c|c|c|}
\hline $\begin{array}{l}\text { Renewable energy } \\
\text { power plant } \\
\text { (VSPP) }\end{array}$ & $\begin{array}{l}\text { Type of } \\
\text { renewable } \\
\text { energy }\end{array}$ & $\begin{array}{l}\text { Electrical } \\
\text { production } \\
\text { (MW/day) }\end{array}$ & $\begin{array}{c}\text { Cost of electricity } \\
\text { production } \\
\left(\text { baht } / \mathrm{kW}^{1}\right)\end{array}$ & $\begin{array}{l}\text { Electricity } \\
\text { production cost } \\
\text { per month }\end{array}$ & $\begin{array}{l}\text { Average } \\
\text { electrical } \\
\text { efficiency }\end{array}$ \\
\hline $\begin{array}{l}\text { Power plant using } \\
\text { rice husk }\end{array}$ & Biomass & 9.24 & 32,340 & $383,903.52$ & 11.87 \\
\hline $\begin{array}{l}\text { Power plant using } \\
\text { wood chips }\end{array}$ & Biomass & 7 & 24,500 & 290,836 & 11.87 \\
\hline $\begin{array}{l}\text { Garbage } \\
\text { management center }\end{array}$ & Refuse & 5 & 25,000 & 20,774 & 0.87 \\
\hline $\begin{array}{l}\text { Power plant using } \\
\text { garbage }\end{array}$ & Refuse & 1 & 5,000 & $4,354.80$ & 0.83 \\
\hline $\begin{array}{l}\text { Organic fertilizer } \\
\text { and energy } \\
\text { production plant }\end{array}$ & Refuse & 10.48 & 52,400 & $43,542.30$ & 0.87 \\
\hline $\begin{array}{l}\text { Power plant using } \\
\text { wind energy }\end{array}$ & Wind & 0.2 & 1,040 & $1,470.96$ & 1.41 \\
\hline $\begin{array}{l}\text { Royal project } \\
\text { (Lukphradabos) }\end{array}$ & Wind & 0.037 & 192.4 & 272.13 & 1.41 \\
\hline $\begin{array}{l}\text { Company producing } \\
\text { electricity from } \\
\text { solar energy }\end{array}$ & Solar & 0.0420 & 525 & 434.90 & 0.83 \\
\hline Pumping station & Hydro & 0.45 & 418.5 & $2,094.66$ & 5.01 \\
\hline $\begin{array}{l}\text { Power plant using } \\
\text { geothermal energy }\end{array}$ & Geothermal & 0.3 & Pilot project & Pilot project & $\begin{array}{l}\text { Pilot } \\
\text { project }\end{array}$ \\
\hline
\end{tabular}

${ }^{1}$ Energy Policy and Planning Office, Ministry of Energy, 2554, Electricity Use and Electricity Production of Thailand. Bangkok: Energy Policy and Planning Office.

${ }^{2}$ Energy Policy and Planning Office, Ministry of Energy. n.d, Adder Program. Retrieved on November 21, 2013 from http://www.eppo.go.th/power/powerN/PICP/File/(12)/(4).pdf.

${ }^{3}$ Metropolitan Electricity Authority. 2013. VSPP Price. Retrieved on November 21, 2013 from http://www.mea.or.th/download-file/index.php?ref=oGS3BHj1oGWapKESnJE4nKOxoFM3p0ky oJkanKETnJI4oaOCoKS3EHkhoJ9anKE0nJA4LDoSo3QoSo3Q. 
4.3 Analysis of the environmental impacts resulting from electricity generation by very small power producer

As shown in Fig. 1, the scope employed in assessing the environmental impact incurred in electricity generation is based on the impacts resulting from raw material acquisition transportation and storage, electricity generation and waste management; the input and output in all of which are as follows:

In assessing the environmental impacts incurred in electricity generation by VSPPs using renewable energy, the findings can be concluded as follows.

\subsubsection{Biomass energy}

In agricultural processes such as rice harvesting and milling, biomass is acquired as a byproduct, though together with some dust particles; depending on the type, transportation and transference of the biomass. If it is a power plant in a factory where biomass is a byproduct, no transportation but only the transference of the biomass is required. In case of the transportation, certain fuels like oil or natural gas are used and subsequently cause some air pollution. In the storage of the biomass, there are some dust particles left behind. To deal with this problem, the power plants under observation have the roof and wall of the storehouse covered all around with shading net. Besides, water is sprayed to prevent the spread of dust particles. In the transference process, the fork lift truck is used, and fuel is needed to power the truck as well as for the conveyor belts, of which there are two types the close and open ones, in feeding the raw material into the electricity generation system. The use of the fork lift truck as well as the open-type conveyor belt poses problems from fugitive dust particles. During the observation, the operational personnel use personal protective equipment.

In generating electricity from biomass, the boilers burning the biomass need water for steam production. Water conditioning is necessary so as to prevent scale formation and the subsequent abrasion

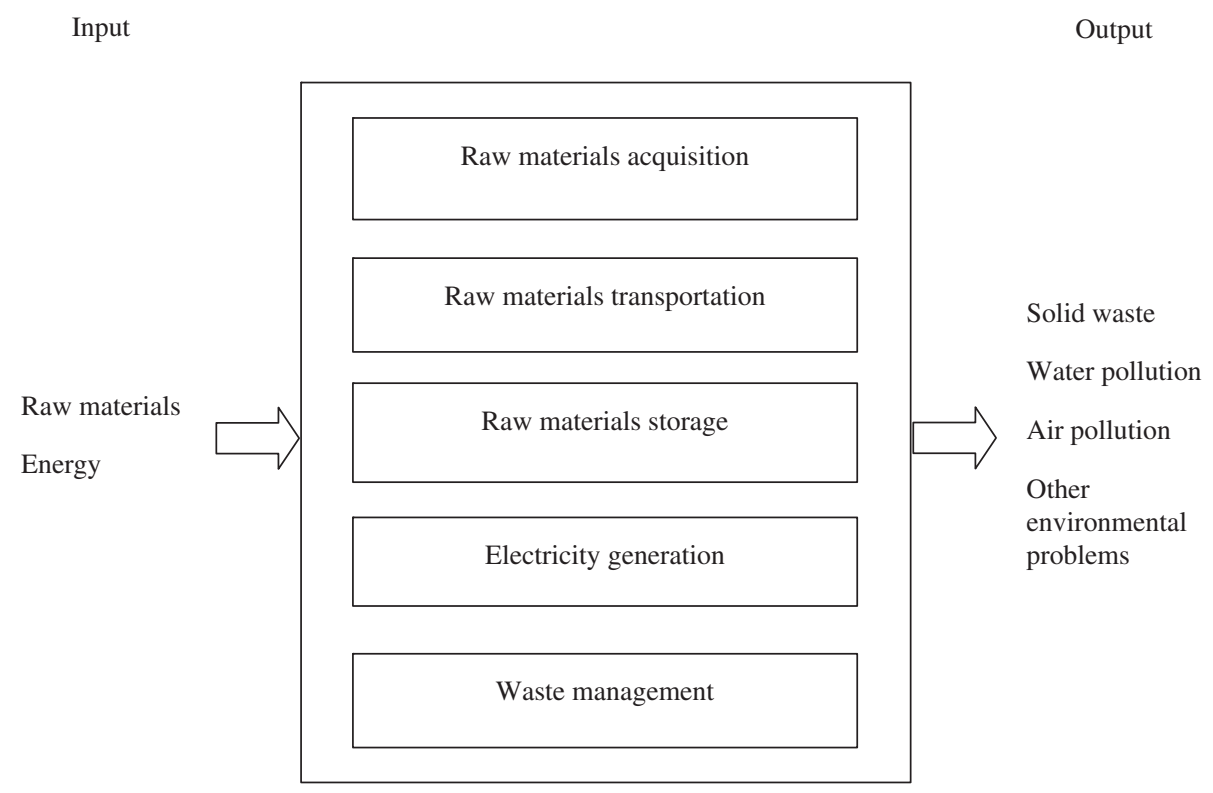

Figure 1: The scope employed in assessing the environmental impacts incurred in electricity generation by very small power producer. 


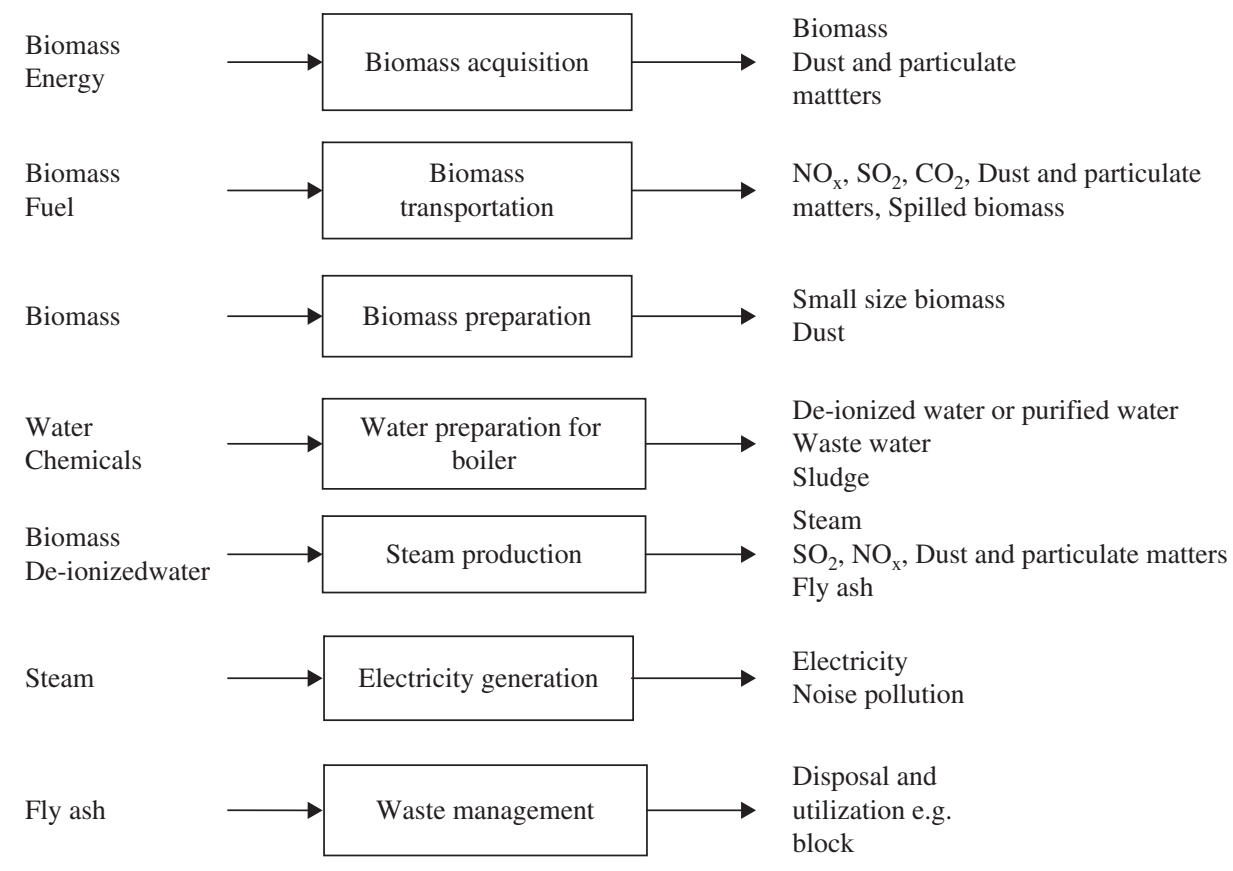

Figure 2: Pollution from electricity generation using biomass.

of the steam boilers. Certain chemical substances are used to make the water free of the elements and ions leading to scale formation. However, some residues and wastewater are unavoidable after the process. The purified water from the process is then used as a raw material in producing steam to turn the turbines in electricity generation. The biomass prepared is then used as the fuel in the combustion in order to produce steam. Certain air pollutants are emitted during the combustion. The most common ones that need to be monitored with reference to the standard allowed are sulfur dioxide $\left(\mathrm{SO}_{2}\right)$, nitrogen oxide $\left(\mathrm{NO}_{\mathrm{x}}\right)$ and dust particles. Sometimes, there is also some tar left behind in the combustion chamber. The steam from the boiling water is used to turn the turbines and run the generators, during which there is some noise problem from the engines used. For the waste management, the ash from the combustion must be disposed of properly or can be recycled, for example by compressing into a block (Fig. 2).

\subsubsection{Refuse-derived energy}

The use of refuse as the raw material in electricity generation discussed in this study concerns two methods: the use of refuse as a fuel in the combustion or in the form of heat energy and the use of landfilled solid waste, which will lead to decomposition and subsequent methane fuel.

1. As for the use of refuse to produce heat, in the combustion the materials mostly used in the plants observed are food and organic wastes, with plastic, paper, glass and metal wastes coming behind. Combustible waste with not too high moisture content is hand-sorted through the conveyor belt, which is powered by electricity. In the observation, though the waste sorting personnel use individually or personal protective equipment, they are not fully protected. There are also problems of the odor and hazardous wastes. 
For the transportation and transference of the refuse, the power plant with the refuse sorted in the premises only needs to have it transferred through the conveyor belt or by a fork lift truck, both of which involve some spillage. But for the refuse sorted outside the plant, fuel is required in its transportation, which leads to air pollution. Spillage is also possible if the refuse is not properly wrapped or covered with shading net.

In the production of steam in the boilers, certain chemical substances are used to deprive the water of the elements and ions, which lead to scale formation and subsequent abrasion of the steam boilers, leaving some residues and wastewater behind. The resulting purified water is then used in producing the steam to turn the turbines in electricity generation. The waste sorted can be used as the fuel in the later combustion.

The burning of solid waste to produce the heat used in the boilers, in addition to the hot steam used to drive the turbine and generator, leads to certain air pollutants including dust particles, nitrogen oxide $\left(\mathrm{NO}_{\mathrm{x}}\right)$, carbon dioxide, carbon monoxide, as well as some possible noise pollution from the electricity generators. The ash left behind from the combustion can be recycled (Fig. 3).

2. For landfill energy, solid waste used as the raw material is hand-sorted by people using some personnel protective equipment through the conveyor belt, which is powered by electricity. Only biodegradable and non-hazardous refuse is used in the landfill. The subsequent environmental impacts include bad odor and spillage during transportation. In transporting the solid waste, which must be wrapped in plastic to the landfill site, there is some air pollution, depending on the energy used.

The landfill must be properly conditioned to prevent undesirable environmental impacts, for example by lining it with high-density polyethylene (HDPE), and installing gas collection pipes and leachate collection pipes. The end product from the landfill is methane gas, which is used in electricity

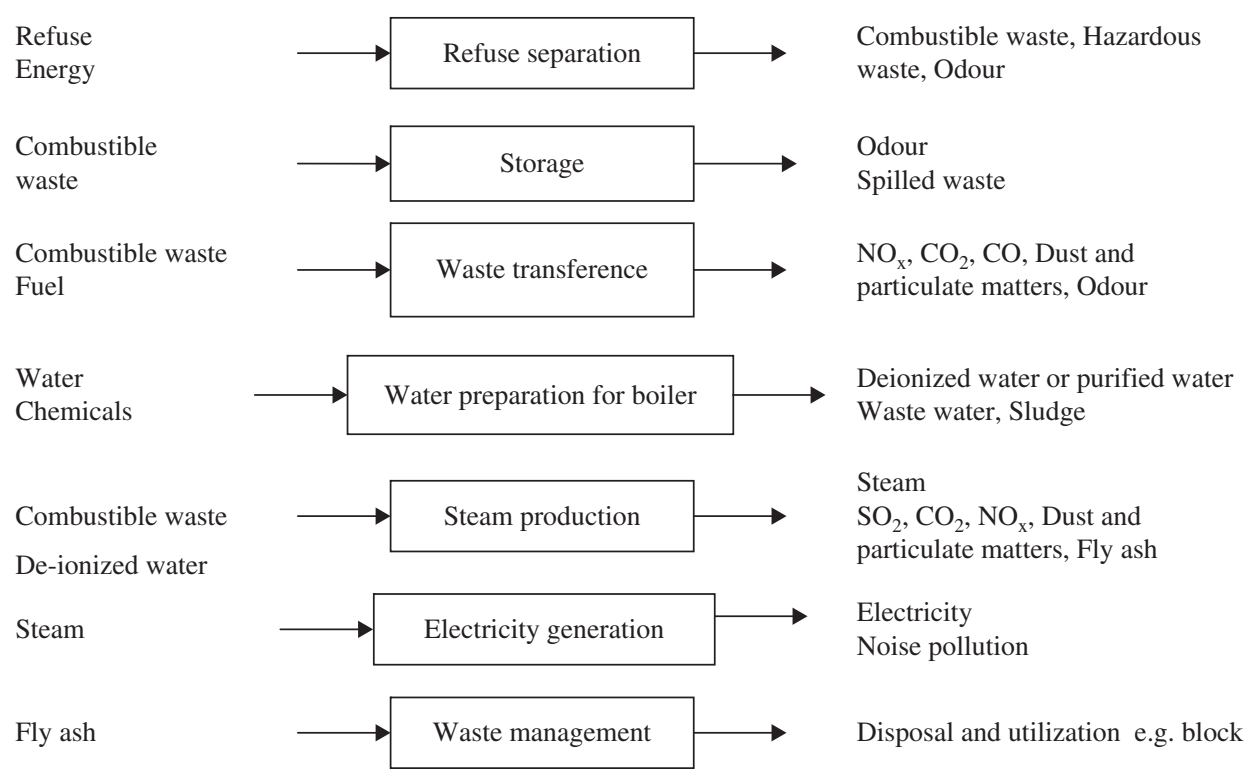

Figure 3: Pollution from electricity generation using refuse. 


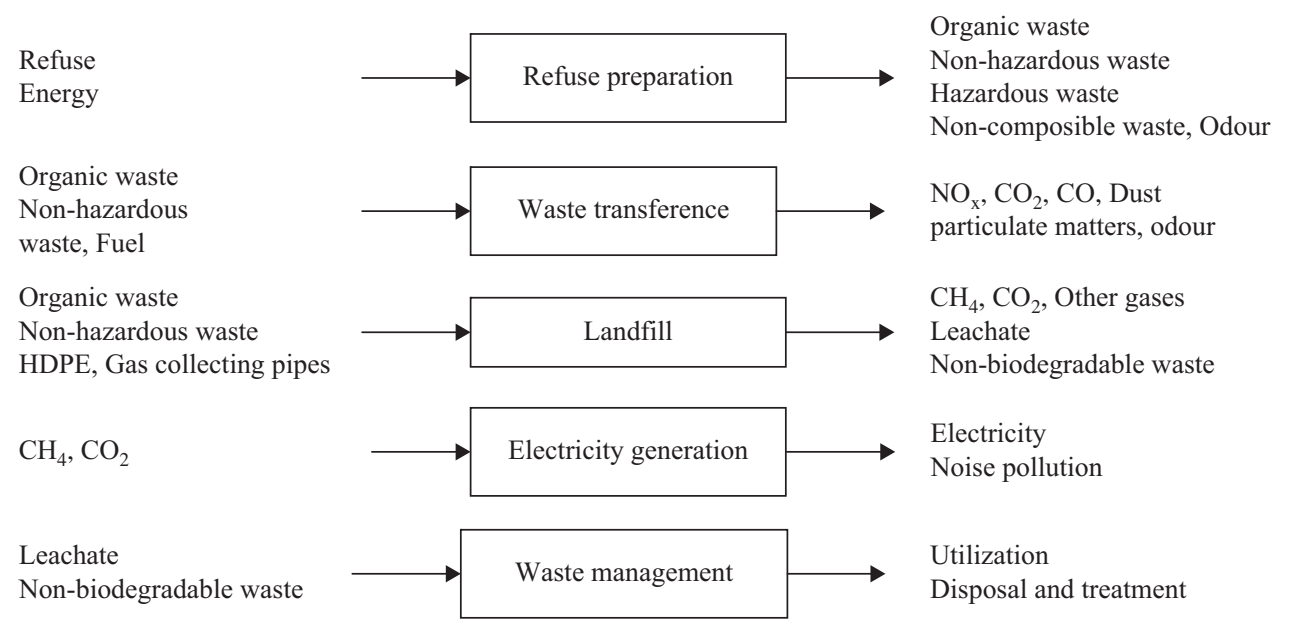

Figure 4: Pollution from electricity generation from landfill.

generation. In addition, there are carbon dioxide and a little amount of other gases, as well as leachate, which must be treated in the treatment ponds. In the electricity generation from the methane acquired, there is some noise pollution from the engines such as the electricity generators. In terms of the management of the waste from the process, like leachate and non-biodegradable waste left behind, appropriate disposal and treatment are applied (Fig. 4).

\subsubsection{Wastewater}

In the process of raw material preparation, wastewater is collected in the wastewater collection ponds through electric pumps. Before being conveyed to the fermentation ponds, such wastewater must be conditioned in order to adjust its acidity. Usually, the power plant producing electricity from biogas created by wastewater treatment is located within the premises where the wastewater collection ponds are located; thus, no vehicle is needed in the transportation. When the wastewater has been adjusted to the right condition, it is pumped to the fermentation ponds, where certain microorganisms and chemical substances are added to make the fermentation condition appropriate. The final product is methane gas. There are also carbon dioxide, hydrogen sulfide, residues, the treated water and odor. The biogas to be used in electricity generation must be conditioned, for example having its moisture content reduced and particulates removed. In such processes, certain chemical substances and energy are used, leaving some residues and odor behind. In the process of electricity generation using the biogas acquired, there is some noise pollution from the machines involved. In the waste management, the wastewater from the fermentation process is treated in the stabilization pond or with other methods and can be used for watering plants. The residues left behind, if toxic, need to be properly treated (Fig. 5).

\subsubsection{Geothermal energy}

In the raw material acquisition process, getting the geothermal energy in the form of hot water and hot steam to generate electricity involves drilling, which requires some energy and water. The water mineral content depends on the source and water temperature. From the observation of the plants studied, the temperature of the hot water and steam acquired is not high enough to generate 


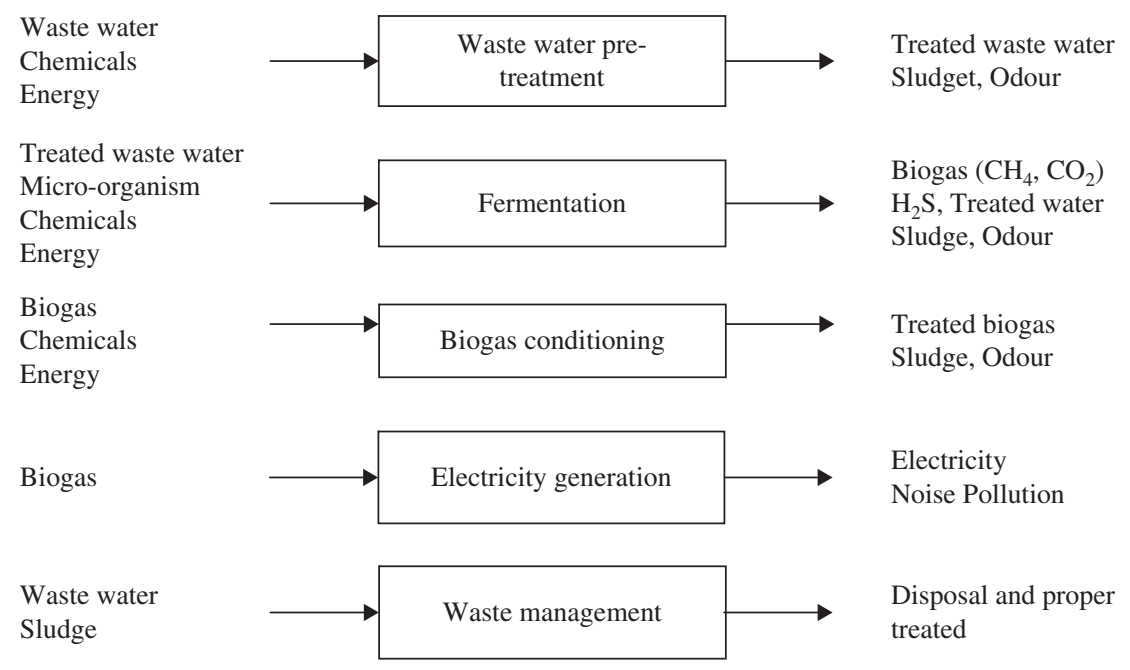

Figure 5: Pollution from electricity generation from wastewater.

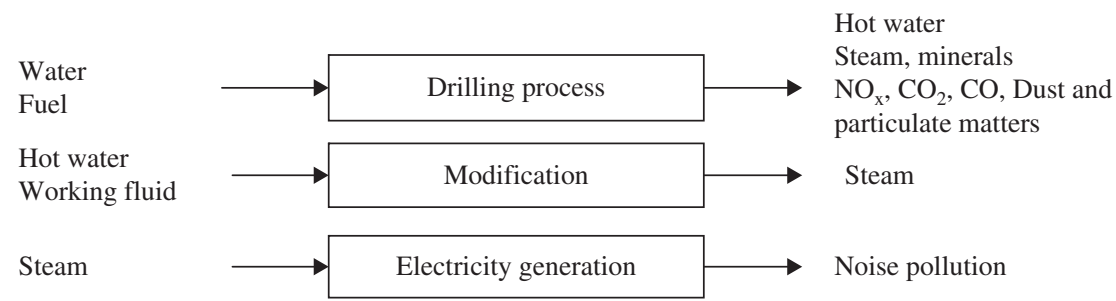

Figure 6: Pollution from electricity generation from geothermal energy.

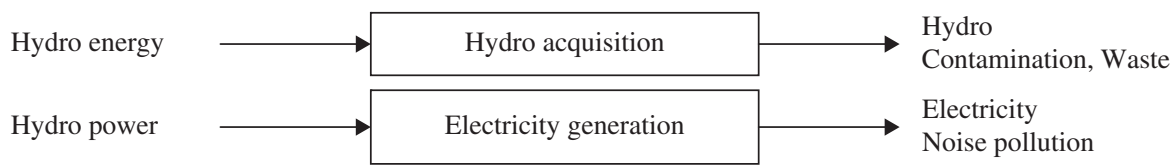

Figure 7: Pollution from electricity generation from hydro energy.

electricity; thus, working fluid is added to raise the temperature. In the drilling, there is some air pollution caused by the fuel used and some noise pollution from the machines used. In the electricity generation process, the hot steam is used to drive the turbines and electricity generators. In accordance with Kagel et al. [5], pollution caused by electricity generation using geothermal energy is negligible as there is no combustion of any fuel (Fig. 6).

\subsubsection{Hydro energy}

In the raw material acquisition, water is pumped or collected using certain energy. Filters are used to prevent dirt particles from damaging the machines involved. In using water energy to produce electricity, water pressure is used to drive the generators, causing some noise impacts from the machines involved (Fig. 7). 


\subsubsection{Wind energy}

Electricity can be produced directly from the wind energy used to drive the generator. In addition to some noise caused by the turbines and generators, electricity generation using wind energy results in negligible pollution (Fig. 8).

\subsubsection{Solar energy}

Solar energy can be directly used to produce electricity through solar cells. The electricity acquired must be appropriately converted using the inverter. In the scope of the environmental impacts referred to in this study, electricity generation using solar energy does not cause any environmental impact (Fig. 9).

As compared in Table 5, electricity generation using hydro, wind and solar energy incur negligible environmental impacts, except for the noise pollution from the machines involved, which is considered an insignificant impact.

For electricity generation using biomass and refuse-derived energy, in which combustion is involved, there are pollution problems in every step analyzed. Besides, there are wastewater and residues left behind in the process of water preparation to produce hot steam.

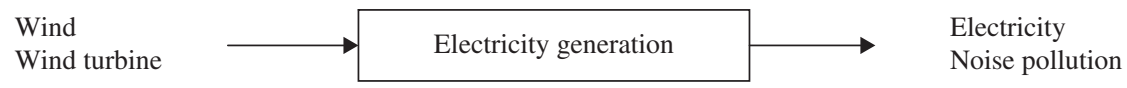

Figure 8: Pollution from electricity generation from wind energy.

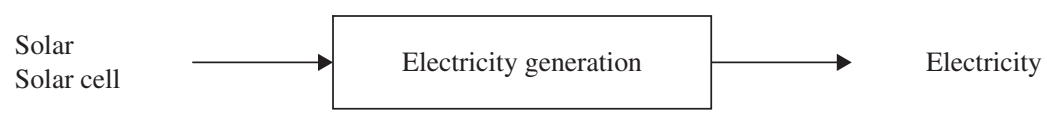

Figure 9: Pollution from electricity generation from solar energy.

Table 5: Analysis of the environmental impacts caused by electricity generation using renewable energy.

\begin{tabular}{lccccc}
\hline & \multicolumn{5}{c}{ Environmental impacts } \\
\cline { 2 - 6 } $\begin{array}{l}\text { Renewable } \\
\text { energy source }\end{array}$ & $\begin{array}{c}\text { Raw material } \\
\text { acquisition }\end{array}$ & Transportation & Storage & Production & Waste management \\
\hline Biomass & $\checkmark$ & $\checkmark$ & $\checkmark$ & $\checkmark$ & $\checkmark$ \\
Refuse & & & & & $\checkmark$ \\
$\quad$ Combustion & $\checkmark$ & $\checkmark$ & $\checkmark$ & $\checkmark$ & $\checkmark$ \\
$\quad$ Refill & $\checkmark$ & $\checkmark$ & & $\checkmark$ & $\checkmark$ \\
Wastewater & $\checkmark$ & & & $\checkmark$ & \\
Geothermal & $\checkmark$ & & & $\checkmark$ & \\
Wind energy & $\checkmark$ & & & \\
Solar energy & & & & & \\
\hline
\end{tabular}




\subsection{Measures in environmental management of very small size renewable energy power plants}

This study suggests the measures in environmental management in every step of electricity generation of very small size renewable energy power plants ranging from the raw material acquisition to the disposal of waste from electricity production.

\subsubsection{Biomass and combustible refuse}

The raw material source should be in the vicinity to the power plant for the convenience in transportation and storage. Apart from the problem of the moisture content, biomass particulates can diffuse and refuse can stink. Another point of concern is that the supply must be sufficient to satisfy the required production capacity. It is, thus, advisable to make a contract with reliable suppliers and stock the raw materials in case of the lack thereof. The raw materials should have an appropriate level of moisture content, for example $<30 \%$ for wood waste. Those with high level of moisture content must be left in the sun to dry or left for some time in the storehouse for their moisture content to decrease. Besides, they should be broken down to very small sizes for their complete combustion. There should not be a lot of particulates mixing with the biomass.

The water to be used in the steam boilers must be treated by getting rid of the minerals leading to scale formation and the subsequent abrasion of the steam boilers. Most of the abrasion is caused by the acidity of the water, with gases and oxygen mixed in the water. Several methods can be used in water treatment. For example, certain chemical substances such as polyaluminum chloride can be used to cause the residue to aggregate and then separate it. Or certain apparatus such as deaerator and oxygen scavenger can be installed. During the transportation, the trucks used should be covered with cloth to prevent spillage and particulate emissions. The trucks used in transporting the raw materials must be regularly checked with their transportation details recorded and followed up. In the storage, the raw materials should be kept in a storehouse with a translucent roof in order that the sunlight can help reduce the moisture content of the raw materials, and with a secure wall to prevent the moisture from outside and the particulate emissions. If the storehouse is in a residential community, it should be covered with shading net for better prevention of particulate emissions. Besides, water should be sprayed around the heap of the raw materials and no smoking signs should be placed in the area. In conveying the raw materials to the burning oven, proper measures should be applied in preventing spillage and fugitive particulate emissions. Operational personnel and those who are in the vicinity must use individually protective equipment.

In the combustion, the combustion chamber should be of high efficiency, for example that in the fluidized bed incinerators [6], which give complete combustion and leave no tar residue behind. In electricity generation, the heat from the combustion is used to change the water in the boiler into steam in order to drive the turbines and generators. However, the water must be appropriately conditioned before. With respect to the treatment of the pollutants from the combustion, mainly the air pollution from the particulate matters, sulfur dioxide, nitrogen oxide; apparatus for air pollution treatment like cyclone, electrostatic precipitation and wet scrubber are used. The pollutants treated must pass the standards set by the Department of Industrial Works and the Pollution Control Department, which must regularly check whether the quality of the air emitted from the exhaust pipes meets the standards required or used (continuous emission monitoring system, CEMS) For water pollution, wastewater must be further treated, for example in the stabilization pond and oxidation pond and then can be recycled if there is no contamination left behind. The residues, if found toxic, must be properly treated before being recycled. For the wastes or byproducts, like ash from the combustion, if considered hazardous, there must be notification on their disposal according to the processes required by the Department of Industrial Works. If not considered hazardous, there 
must be identification of their recycling, for example in the production of bricks. Such wastes or byproducts must be properly kept in order to prevent particulate emissions. For other quality controls, like noise pollution control, personnel working in the area with noisy equipment such as boilers and generators must use individually or personal protective equipment like ear plugs, or ear mugs. Growing perennial plants like tall trees and medium-sized bushes around the power plants can help prevent particulate emissions, noise impact and odor to the residential community in the vicinity.

\subsubsection{Landfill refuse}

The amount appropriate for the electricity generation using landfill refuse is over one million tons (landfill methane outreach program [7]). Sorting refuse is of importance, in order to separate biodegradable or organic waste from non-organic waste and separate refuse that can cause explosion on landfill property. Sorting refuse is carried out through the conveyor belts by personnel who must use individual or personal protective equipment like gloves, boots and mouth covering cloth. The refuse must be wrapped with specially thick plastic according to the standard set in its transportation to prevent water from dampening it and prevent spillage on the way. The deck of the truck used should be covered with cloth.

For the preparation of the landfill, the size must be appropriate to the amount of the refuse, with the depth of at least $12 \mathrm{~m}$, and working capacity of no $<20$ years, and with anti-seepage system covering all over the bottom and side surfaces before the refuse is filled in. After the landfill is filled up, or there is no more use of the property, the landfill is to be closed with anti-seepage lining. Clay or synthetic lining sheets with low seepage rate can be used. According to the standard set, a layer of sheets made of compressed clay of $60 \mathrm{~cm}$ in thickness with the seepage rate of $<1 \times 10^{-7} \mathrm{~cm}$ per second, or sheets made of HDPE with the thickness of at least $1.5 \mathrm{~mm}$ can be used to line all the interior [8]. A pipe system must be installed in order to collect and dispose of the refuse's leachate. There must be a rain water drainage system for the rainwater falling onto the landfill. Above the anti-seepage layer, the pipe system collecting the refuse's leachate is installed consisting of PVC or HPDE pipes of at least 4 in in diameter, with holes and covered with synthetic fiber filter sheets and placed within a layer of pebble or round sand, with the seepage rate of $<1 \times 10^{-7} \mathrm{~cm}$ per second and of not $<30 \mathrm{~cm}$ in thickness. The quality of the wastewater discharged outside the landfill property must be within the standard criteria of disposed wastewater quality according to the Industrial Works Act [8]. Bio-extract should be sprayed in order to reduce the odor from the landfill and the refuse.

In extracting the biogas, there must be a system to ventilate and control the gas resulting from the decomposition of the refuse in the landfill, which is mainly methane, to prevent the explosion, fire and disturbing odor. The system controlling the gas in the landfill must be designed to prevent the concentration of the methane gas. In order to control the ventilation of the methane gas from the landfill, a pipe must be placed vertically and the equipment to extract the gas from the landfill, which is called active control, must be installed in order to exploit the gas as the fuel. In the case that there is a large amount of landfill gas, the gas must be burned with flares. The resulting gas must be disposed of in compliance with the air quality standard. For the gas relay pipe and gas measuring equipment, there must be a regular examination to prevent leakage, and the concentration of the gas must be regularly measured. There must be quality improvement and cleansing of the gas, for example to remove water, carbon dioxide, corrosive substances, alkaline metal and particulates.

In electricity generation, the biogas from a general landfill, which consists of $50 \%$ methane gas, $40 \%-50 \%$ carbon dioxide, $0.5 \%-1 \%$ of hydrogen, oxygen, nitrogen and other gases, is used to drive the turbines and generators. Personnel working in the vicinity must use equipment to protect themselves from the engine noise. 


\subsubsection{Wastewater}

Wastewater with considerably high dirt content of COD/N/P (100:2.2:0.4) is suitable for the fermentation to produce methane gas, which can be used in energy production. The raw material (wastewater) should be in the same area for the convenience of conveying it to the wastewater treatment system. The wastewater must be of adequate amount and with the COD content at the appropriate and stable level. In treating wastewater through fermentation, the treatment condition and treatment technology employed must be appropriate, for example the anaerobic fixed film system. The biogas acquired from the fermentation, which may be contaminated, must be treated before being used for electricity generation, for example by using the wet scrubber and gas moisture reduction equipment. In electricity generation, there should be apparatus to reduce the noise, and the operational personnel should use personally protective equipment. The wastewater left behind after the treatment should be processed in the oxidation pond and stabilization pond according to the standard criteria before being used, for example in watering plants.

\subsubsection{Geothermal energy}

The raw materials such as hot water and hot steam must have the temperature and pressure appropriate for electricity generation, which is above $180^{\circ} \mathrm{C}$, and at a pressure above the value of 10 atmosphere. In drilling the hot water, there must be a system to prevent the sinking of land at the surface. The water should be conveyed through insulated iron pipes in order to stabilize its temperature, and it should be kept in a feed tank to control its temperature. Metal residues in the water should be filtered to prevent the damage caused to the electricity generation system. For the steam left over from the electricity generation, its pentane, which is a working fluid substance used in controlling the temperature of water, will be isolated for reuse. The hot water and hot steam left over are also to be recycled.

\subsubsection{Wind energy}

Wind is a clean and naturally created energy. The wind used in electricity generation must be of the speed of no $<5 \mathrm{~m} / \mathrm{s}$, and of a regular speed. The size of the turbines used must suit the wind speed. The height of the turbines and the space between each one depends on the location, wind direction and wind passage. In the electricity generation using wind energy, there might be some noise impacts caused by the turbines, so careful consideration must be put into the correspondence between the size of the turbines and the wind speed.

\subsubsection{Hydro energy}

Hydro is a clean energy with potential in electricity generation. The amount and the pressure of water must be appropriate in order to be used to drive the turbines. Filters should be installed in the conveyor pipes to prevent green and wood waste from getting into and subsequently damage the system. The metal sheet noise prevention equipment with interior foam layer and exterior insulation can be used to reduce the noise impacts from the generators to the community nearby.

\subsubsection{Solar energy}

According to the environmental impact analysis within the scope of the study, electricity generation using solar energy brings about no environmental impact. To prevent any possible environmental impacts and ensure the most suitable condition for the utmost efficiency in electricity generation, the temperature and moisture content of the sunlight must be appropriate. Cleaning the solar cells is also of importance. 


\section{CONCLUSION}

Regarding the analysis of the environmental impacts with reference to the scope of raw material acquisition, raw material transportation, raw material storage, electricity generation and waste management, it is found that the biomass and refuse-derived energy bring about environmental impacts in their every step of electricity generation. The worst pollution caused by electricity generation using biomass and refuse-derived energy is air pollution, which occurs in almost every step analyzed. The biogas energy produced from wastewater incurs less environmental impact than the biomass energy as there is no combustion, the step which can most negatively affect the environment when compared with other steps. Whereas electricity generation using wind and that using solar energy causes least environmental impact, the only one of which is the noise from the electricity generators.

This study suggests the measures in the environmental management in electricity generation using renewable energy as follows:

- Measures concerning raw material acquisition - The raw materials should be in the vicinity to the power plant and are in sufficient amount and of appropriate quality. It is advisable to have viable backup raw material sources and make a purchase contract for the materials, which must be purchased.

- Measures concerning transportation - There should be a system in supervising the transportation of the raw materials to the plant and in preventing the spillage of the raw materials along the way, for example by using shading net to cover them.

- Measures concerning storage - The raw materials should be properly stored for the convenience of use. The raw materials in the categories of biomass and refuse should have low moisture content and of the amount sufficient for the production and should be stored in a closed area in order to prevent particulate emissions.

- Measures concerning electricity generation - The technology employed should be appropriate and efficient. There should be measures in preventing the noise caused by electricity generation.

- Measures concerning waste management - The waste incurred should be appropriately recycled. In case of hazardous wastes, relevant offices must be notified.

\section{SUGGESSION ON/CONCERNING POLICIES}

1. Currently, the relevant organizations have their own regulations on environmental management for power plants but it is difficult for implementation as their thought based on their roles. Therefore in the future, they should integrate their regulations for environmental management to only one as it is practical.

2. The government's policies should support only power plants that have adequate and appropriate raw materials and available resources. And there should be restriction on the concession granted for electricity generation using renewable energy that causes environmental impacts.

3. The measures and standards used at present are not inclusive of all the pollutions incurred, but only cover those which are evident such as air pollution and water pollution. Moreover, at present there is yet no environmental measure or standard clearly applicable to very small size power plants. Thus, analysis of every step of electricity generation using renewable energy is essential in order to find out/come up with suggestions on comprehensive environmental management measures.

4. A power plant with a production capacity of $<1 \mathrm{MW}$, which does not need to obtain concession in order to generate electricity, should be under the supervision of a local government, as its electricity generation may cause some environmental impacts. 


\section{REFERENCES}

[1] Beyond Petroleum (BP), BP Statistical Review of World Energy. June 2010. BP plc.: UK, 2010.

[2] Varun, P.R. \& Bhat, I.K., Energy, economics and environmental impacts of renewable energy systems. Renewable and Sustainable Energy Review, 13(9), pp. 2716-2721, 2009. doi: http:// dx.doi.org/10.1016/j.rser.2009.05.007

[3] Electricity Generating Authority of Thailand, http://www.prinfo.egat.co.th

[4] US. EPA, http:www.epa.gov/rdee/energy-and-you/affect/air-emissions.html

[5] Kagel, A., Bates, D. \& Gawell K. A Guide to Geothermal Energy and the Environment, Geothermal Energy Association: United States of America, 2007. doi: http://dx.doi. org/10.2172/897425

[6] Buranasak Madmai. Biomass to energy. Technology Promotion Association, 36(April-May), pp. 63-65, 2009.

[7] US. EPA, http://www.epa.gov/imop/index.html

[8] Department of Pollution Control. Ministry of Science Technology and Science. Standard Measures and Guidelines for Community Garbage Management. 5th edn. Khurusapha the Teachers's Council of Thailand: Bangkok, 2001. 